\title{
A multicenter, randomized, double-blind, dose-finding study of condoliase in patients with lumbar disc herniation
}

\author{
Yukihiro Matsuyama, MD, PhD, ${ }^{1}$ Kazuhiro Chiba, MD, PhD, ${ }^{2}$ Hisashi Iwata, MD, PhD, ${ }^{3}$ \\ Takayuki Seo, PhD, ${ }^{4}$ and Yoshiaki Toyama, MD, PhD ${ }^{2}$
}

\begin{abstract}
${ }^{1}$ Department of Orthopaedic Surgery, Hamamatsu University School of Medicine, Hamamatsu, Shizuoka; ${ }^{2}$ Department of Orthopaedic Surgery, Keio University School of Medicine, Tokyo; ${ }^{3}$ Department of Orthopaedic Surgery, Nagoya Kyoritsu Hospital, Nagoya, Aichi; and ${ }^{\circ}$ Biostatistics \& Data Management Group, Clinical Development, Research \& Development Division, Seikagaku Corporation, Tokyo, Japan
\end{abstract}

OBJECTIVE Chemonucleolysis with condoliase has the potential to be a new, less invasive therapeutic option for patients with lumbar disc herniation (LDH). The aim of the present study was to determine the most suitable therapeutic dose of condoliase.

METHODS Patients between 20 and 70 years of age with unilateral leg pain, positive findings on the straight leg raise test, and LDH were recruited. All eligible patients were randomly assigned to receive condoliase $(1.25,2.5$, or $5 \mathrm{U})$ or placebo. The primary end point was a change in the worst leg pain from preadministration (baseline) to week 13 . The secondary end points were changes from baseline in the following items: worst back pain, Oswestry Disability Index (ODI), SF-36, and neurological examination. For pharmacokinetic and pharmacodynamic analyses, plasma condoliase concentrations and serum keratan sulfate concentrations were measured. The safety end points were adverse events (AEs) and radiographic and MRI parameters. Data on leg pain, back pain, abnormal neurological findings, and imaging parameters were collected until week 52.

RESULTS A total of 194 patients received an injection of condoliase or placebo. The mean change in worst leg pain from baseline to week 13 was $-31.7 \mathrm{~mm}$ (placebo), $-46.7 \mathrm{~mm}(1.25 \mathrm{U}),-41.1 \mathrm{~mm}(2.5 \mathrm{U})$, and $-47.6 \mathrm{~mm}(5 \mathrm{U})$. The differences were significant at week 13 in the $1.25-\mathrm{U}$ group $(-14.9 \mathrm{~mm} ; 95 \% \mathrm{Cl}-28.4$ to $-1.4 \mathrm{~mm} ; \mathrm{p}=0.03)$ and $5-\mathrm{U}$ group $(-15.9 \mathrm{~mm} ; 95 \% \mathrm{Cl}-29.0$ to $-2.7 \mathrm{~mm} ; \mathrm{p}=0.01)$ compared with the placebo group. The dose-response improvement in the worst leg pain at week 13 was not significant $(p=0.14)$. The decrease in the worst leg pain in all 3 condoliase groups was observed from week 1 through week 52. Regarding the other end points, the worst back pain and results of the straight leg raise test, ODI, and SF-36 showed a tendency for sustained improvement in each of the condoliase groups until week 52. In all patients at all time points, plasma condoliase concentrations were below the detectable limit $(<100$ $\mu \mathrm{U} / \mathrm{ml}$ ). Serum keratan sulfate concentrations significantly increased from baseline to 6 hours and 6 weeks after administration in all 3 condoliase groups. No patient died or developed anaphylaxis or neurological sequelae. Five serious AEs occurred in 5 patients ( 3 patients in the condoliase groups and 2 patients in the placebo group), resolved, and were considered unrelated to the investigational drug. Severe AEs occurred in 10 patients in the condoliase groups and resolved or improved. In the condoliase groups, back pain was the most frequent AE. Modic type 1 change and decrease in disc height were frequent imaging findings. Dose-response relationships were observed for the incidence of adverse drug reactions and decrease in disc height.

CONCLUSIONS Condoliase significantly improved clinical symptoms in patients with LDH and was well tolerated. While all 3 doses had similar efficacy, the incidence of adverse drug reactions and decrease in disc height were dose dependent, thereby suggesting that $1.25 \mathrm{U}$ would be the recommended clinical dose of condoliase.

Clinical trial registration no:: NCT00634946 (clinicaltrials.gov)

https://thejns.org/doi/abs/10.3171/2017.7.SPINE161327

KEY WORDS chemonucleolysis; condoliase; lumbar disc herniation; dose-finding study; less invasive; leg pain

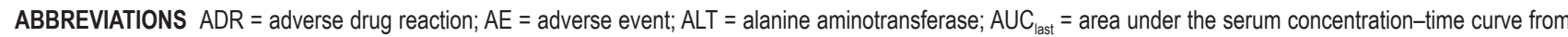
baseline to last sampling time; $\mathrm{C}_{\max }=$ maximum serum concentration; IgE = immunoglobulin $\mathrm{E} ; \mathrm{LDH}=$ lumbar disc herniation; ODI = Oswestry Disability Index; $\mathrm{SLR}=$ straight leg raise; $T_{\max }=$ time to reach maximum serum concentration; VAS = visual analog scale.

SUBMITTED December 4, 2016. ACCEPTED July 28, 2017.

INCLUDE WHEN CITING Published online February 9, 2018; DOI: 10.3171/2017.7.SPINE161327. 
$\mathrm{L}$ UMBAR disc herniation (LDH) is a medical condition manifested by symptoms such as leg pain, low-back pain, and numbness resulting from spinal cord and nerve root compression through the protrusion of intervertebral disc tissue into the spinal canal. ${ }^{12}$ Because LDH frequently occurs in 20- to 40-year-old working adults, the social and financial losses caused by restricted daily activities are substantial problems. ${ }^{26}$

LDH is generally treated conservatively, and approximately $90 \%$ of patients can be cured with conservative treatment. ${ }^{11,13}$ Surgery is only recommended when symptoms do not improve with conservative treatment. Less invasive surgical techniques were recently introduced to reduce the physical and psychological burdens on patients and thereby achieve early rehabilitation. ${ }^{2,3,30}$ However, these procedures require a high degree of skill and have a long learning curve. ${ }^{27}$ The high initial cost of new equipment, including endoscopes, also limits the opportunities for medical institutions to offer these less invasive options to patients.

Chemonucleolysis involves the injection of an enzyme into the intervertebral disc to dissolve the nucleus pulposus,${ }^{29}$ thereby reducing intradiscal pressure on the nerve root and improving LDH symptoms. This treatment is considered an intermediate treatment for LDH and falls between conservative treatment and surgical treatment. ${ }^{9}$

Condoliase (chondroitin sulfate $\mathrm{ABC}$ endolyase) is a pure mucopolysaccharidase derived from the gram-negative rod Proteus vulgaris. ${ }^{29}$ Condoliase has high substrate specificity for chondroitin sulfate and hyaluronic acid, which are glycosaminoglycans on proteoglycans that are abundant in the nucleus pulposus of the intervertebral disc, and lacks protease activity. ${ }^{10}$ Therefore, condoliase has the potential to become a safe and effective chemonucleolysis drug.

We previously conducted the first clinical study of condoliase in patients with $\mathrm{LDH}$ in Japan and reported the results of the study. ${ }^{17}$ In the present randomized, double-blind, placebo-controlled study, we investigated the most suitable therapeutic dose of condoliase by evaluating its pharmacokinetics, efficacy, and safety in patients with LDH.

\section{Methods \\ Study Design}

The study was a randomized, double-blind, placebocontrolled, multicenter clinical trial conducted at 38 medical institutions in Japan (clinical trial registration no. NCT00634946, clinicaltrials.gov). The institutional review board at each study site approved the study. All patients provided written informed consent.

Patients were recruited through a rigorous selection process and received an intradiscal injection of condoliase or placebo. The pharmacokinetics, pharmacodynamics, efficacy, and safety of condoliase were evaluated during a 13-week period after administration. The patients were followed for 52 weeks after administration to evaluate the long-term efficacy and safety of condoliase in the intervertebral disc and its surrounding tissues.

\section{Patient Population}

Patients between 20 and 70 years of age were included if they had 1) unilateral leg pain and positive findings on the straight leg raise (SLR) test $\left(\leq 70^{\circ}\right) ; 2$ ) a contained LDH (i.e., protrusion or subligamentous extrusion) ${ }^{28}$ at L4-5, L5-6, or L5-S1 verified on MR images; 3) neurological signs consistent with the distribution of compressed nerve roots; 4) no improvement after adequate conservative treatment for $\geq 6$ weeks; and 5) a mean visual analog scale (VAS) score of $\geq 50 \mathrm{~mm}$ for the worst leg pain over 7 consecutive days before enrollment.

Patients were excluded if they 1) had a positive prick reaction to condoliase, 2) had $\mathrm{LDH}$ at 2 or more levels on MR images, 3) had undergone previous lumbar surgery, 4) had a nerve root block less than 3 weeks prior to the time of informed consent, 5) had severe and rapidly progressing neurological deficits (e.g., cauda equina syndrome), 6) had other lumbar spine diseases, 7) were pregnant or breastfeeding, 8) had a body mass index of $\geq 35.0 \mathrm{~kg} / \mathrm{m}^{2}$, 9) were receiving workers' compensation, or 10) had spinal instability including a posterior intervertebral angle of $\geq 5^{\circ}$ on lateral flexion radiographs or vertebral translation of $\geq 3 \mathrm{~mm}$ on flexion-extension radiographs.

\section{Randomization}

All eligible patients were randomly assigned to receive condoliase $(1.25,2.5$, or $5 \mathrm{U})$ or placebo in equal proportions using a minimization protocol. ${ }^{23}$ All patients and investigators were unaware of the study group assignments.

\section{Blinding}

The study was conducted in a double-blind manner, with no information on treatment assignment provided to the investigators, patients, or radiologists in the central imaging facility. The appearance, preparation method, and injection procedure for condoliase and placebo were identical. The pharmacokinetic and pharmacodynamic data and anticondoliase antibody titers were not disclosed throughout the study period to prevent unblinding.

\section{Intervention}

Both condoliase and placebo were lyophilized white powders with identical appearances in vials, with the latter containing all components except for condoliase. Each vial was reconstituted with $4 \mathrm{ml}$ of saline to prepare a solution for injection containing condoliase $(1.25,2.5$, or 5 $\mathrm{U} / \mathrm{ml}$ ) or placebo. There were no differences in color or viscosity between condoliase and placebo after reconstitution.

Under fluoroscopy, a single 1-ml dose of condoliase or placebo was injected into the center of the nucleus pulposus of an intervertebral disc using a 21- to 23-gauge puncture needle as the patient was lying in a lateral recumbent or prone position. All injections were performed by registered board-certified spine surgeons who were well trained in the intradiscal injection technique. The use of general anesthesia, contrast medium, and midline dural puncture was prohibited. To counteract potential anaphylaxis, an intravenous line was established prior to administration. 
All patients were hospitalized for 2 days, including the day of administration; discharged after the 2-day hospital stay; and seen in outpatient clinics at weeks $1,2,4,6,13$, 26,39 , and 52 .

\section{Conservative Treatment}

All patients continued to receive the same conservative treatment that they were receiving at the time of providing informed consent to reflect the actual clinical settings. If necessary, additional conservative treatment was allowed to treat worsening of leg pain or exacerbation of neurological symptoms at the discretion of the investigator. Patients who underwent nerve root blocks or surgery after administration were withdrawn from the study.

\section{Outcome Measures}

The primary end point was a change in the worst leg pain ${ }^{15}$ during the previous 24 hours from preadministration (baseline) to week 13. Patients assessed their own pain levels before going to bed. Pain intensity was measured on a horizontal 100-mm VAS, with $0 \mathrm{~mm}$ representing "no pain" and $100 \mathrm{~mm}$ representing "worst pain ever experienced." The preadministration VAS was measured on the last 7 consecutive days before patient enrollment, and VAS at week 13 was measured on the last 7 consecutive days before observation. This primary end point was selected because leg pain is the main symptom that afflicts patients with LDH, and the efficacy of conservative treatment is usually assessed at approximately 3 months to determine whether surgery is necessary. The secondary end points were changes from baseline in the following items: worst back pain, Oswestry Disability Index (ODI) ${ }^{6,7}$ SF$36,{ }^{8}$ neurological examinations (positive findings on SLR test, hypesthesia, muscle weakness, and deep-tendon hyporeflexia), volume of intervertebral disc and herniated mass, and disc height.

Safety end points were adverse events (AEs), vital signs, laboratory parameters, anticondoliase antibody titers, and imaging parameters (change in disc height, posterior intervertebral angle, vertebral body translation, change in Modic classification, ${ }^{19}$ and change in Pfirrmann classification $^{21,22}$ ). We rated the seriousness and severity of each $\mathrm{AE}$ and assessed its relationship with the investigational drug (condoliase or placebo). All AE data were collected through week 13. Data on leg pain, back pain, abnormal neurological findings, and imaging parameters were collected through week 52 to evaluate the long-term effects of condoliase. Imaging parameters were tabulated as the frequency of the imaging findings based on the following criteria: 1) $\geq 30 \%$ decrease in disc height, 2) posterior intervertebral angle $\geq 5^{\circ}, 3$ ) vertebral body translation $\geq$ $3 \mathrm{~mm}$, 4) change in Modic classification, and 5) change in Pfirrmann classification. All imaging parameters were collected and analyzed independently at the central imaging facility.

\section{Measurement of Imaging Parameters}

Radiographs and MR images were obtained at each study site according to the protocol provided by the central imaging facility. The acquired images were sent to, processed by, and evaluated at the central imaging facility as described below.

Disc height was calculated on lateral neutral radiographs using the following equation: disc height $=$ (anterior disc height + posterior disc height $) /(2 \times$ upper vertebral body height) (Fig. 1A). The posterior intervertebral angle was defined as the angle between the vertebral endplates adjacent to the injected intervertebral disc on a lateral flexion radiograph (Fig. 1B). Vertebral translation was defined as the absolute difference in the distance between the posterior edges of the upper and lower vertebral bodies adjacent to the injected intervertebral disc on a lateral flexion-extension radiograph (Fig. 1C). The volumes of the intervertebral disc and herniated mass were measured using continuous sagittal T2-weighted MRI. ${ }^{5}$ Signal changes in the vertebral body adjacent to the cartilage endplates and the degree of intervertebral disc degeneration were assessed on MR images by using the Modic classification and Pfirrmann classification, respectively.

\section{Pharmacokinetics and Pharmacodynamics}

All patients who were administered condoliase or placebo were subjected to blood sampling. Blood samples were collected before administration; at 6, 24, and 48 hours after administration; and at weeks 1, 2, 6, and 13 . For pharmacokinetic analysis, the plasma condoliase concentrations were determined using a validated condoliase enzyme activity assay before administration, at 6 and 48 hours after administration, and at weeks 1, 6, and 13. For pharmacodynamic analysis, the serum keratan sulfate concentrations were determined using a validated enzyme-linked immunosorbent assay at all sampling times. The maximum serum concentration $\left(\mathrm{C}_{\max }\right)$, area under the serum concentration-time curve from baseline to last sampling time $\left(\mathrm{AUC}_{\text {last }}\right.$ ), and time to reach $\mathrm{C}_{\max }\left(\mathrm{T}_{\max }\right)$ were calculated for the serum keratan sulfate concentration and change in serum keratan sulfate concentration by using the noncompartmental method using SAS software (version 9.1, SAS Institute).

\section{Statistical Analysis}

Power analysis determined that a sample size of 46 patients per treatment group was necessary to detect a difference of $21 \mathrm{~mm}$ in the worst leg pain at week 13 between the condoliase and placebo groups with $90 \%$ power and 2-sided significance of 0.05 using the Dunnett test.

Pharmacokinetic, pharmacodynamic, and efficacy analyses were performed for all randomized patients who received the investigational drug and had at least 1 postadministration assessment. The dose-response relationships of $\mathrm{C}_{\max }$ and $\mathrm{AUC}_{\text {last }}$ were evaluated using the power model and ANOVA.

The primary and secondary efficacy end points were analyzed using the ANCOVA model with the Dunnett test. Covariates, except for the baseline values of the end points, were selected using a stepwise method from the factors that showed a difference between treatment groups. Neurological examinations were analyzed using the Steel test. Missing values were imputed using the last observation carried forward method. The Jonckheere-Terpstra 

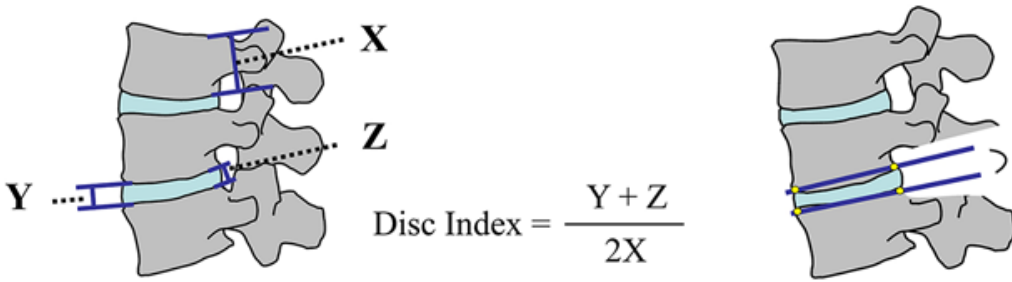

Posterior angle

A

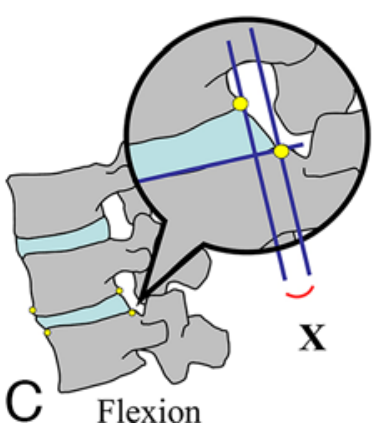

B Flexion

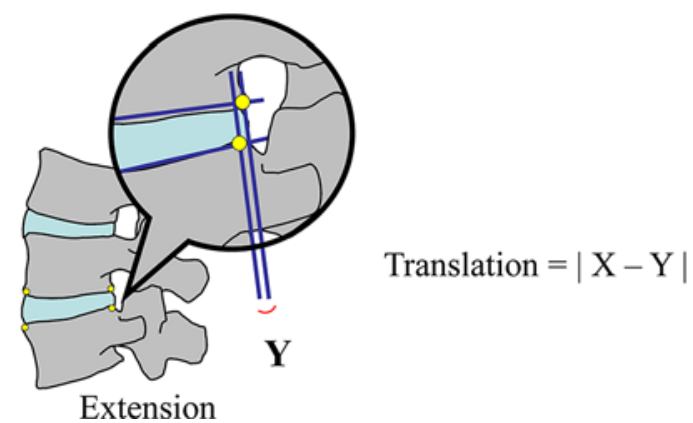

FIG. 1. A: Method for calculating the disc height. When the condition of the upper vertebral body was inappropriate, the anatomical index $X$ was measured at another site. The index was obtained at the same site (anterior or posterior to the same vertebral body) throughout the study. $X$ indicates the upper vertebral body height, $Y$ indicates the anterior disc height, and $Z$ indicates the posterior disc height. B: Method for measuring the posterior intervertebral angle. C: Method for measuring vertebral translation. Regarding the vertebral bodies adjacent to the target intervertebral disc, when the upper disc was behind the lower disc, the measured value became negative. $X$ and $Y$ indicate the distance between the posterior edges of the upper and lower vertebral bodies adjacent to the injected intervertebral disc on lateral flexion and extension radiographs, respectively. Figure is available in color online only.

test was used to evaluate trends among treatment groups. Safety analyses were performed on all randomized patients who received the investigational drug. Trends in the incidences of AEs were analyzed by using the CochranArmitage test. All analyses were performed using SAS software (version 9.2, SAS Institute).

\section{Results}

\section{Patient Characteristics}

A flowchart illustrating patient enrollment is shown in Fig. 2. A total of 266 patients were screened between February 2008 and August 2009. Of these 266 patients, 195 were eligible and randomly assigned to one of the 4 groups (placebo or 1.25-, 2.5-, or 5-U condoliase groups). An investigational drug was administered to 194 of 195 enrolled patients (1 patient in the 2.5 -U group did not receive the designated injection). Of these 194 patients, 176 completed evaluations at week 13, and 147 patients completed evaluations at week 52. Some intergroup differences were observed in age, number of current smokers, and worst back pain (Table 1).

\section{Pharmacokinetics and Pharmacodynamics}

In all patients treated with condoliase, the plasma condoliase concentrations were below the lower limit of detection $(<100 \mu \mathrm{U} / \mathrm{ml})$ at all time points.

The serum keratan sulfate concentrations significantly increased from 6 hours through 6 weeks after administration in all condoliase groups (Fig. 3). The median $\mathrm{T}_{\max }$ was 1.9 days in the 3 condoliase groups $(1.25,2.5$, and $5 \mathrm{U})$. Regarding changes in the serum keratan sulfate concen- trations in the placebo and 1.25-U, 2.5-U, and 5-U groups, the geometrical mean values of $\mathrm{C}_{\max }$ were $42.483,148.311$, 181.554 , and $218.285 \mathrm{ng} / \mathrm{ml}$, and the geometrical mean values of $\mathrm{AUC}_{\text {last }}$ were 1727.644, 3163.450, 3486.067, and $5656.195 \mathrm{ng} \cdot \mathrm{day} / \mathrm{ml}$, respectively. Dose-response relationships were observed for both $\mathrm{C}_{\max }$ and $\mathrm{AUC}_{\text {last }}$ with $95 \%$ CIs for their slopes of $0.08-0.48$ and $0.10-0.74$, respectively $(\mathrm{p}<0.001$ and $\mathrm{p}=0.001$, respectively, ANOVA).

\section{Efficacy}

The change in the worst leg pain from 24 hours before baseline to week 13 was $-31.7 \mathrm{~mm}$ in the placebo group, $-46.7 \mathrm{~mm}$ in the $1.25-\mathrm{U}$ group, $-41.1 \mathrm{~mm}$ in the $2.5-\mathrm{U}$ group, and $-47.6 \mathrm{~mm}$ in the 5-U group. The differences were $-14.9 \mathrm{~mm}(95 \% \mathrm{CI}-28.4$ to $-1.4 \mathrm{~mm} ; \mathrm{p}=0.03)$ in the 1.25 -U group, $-9.3 \mathrm{~mm}(95 \% \mathrm{CI}-22.7$ to $4.0 \mathrm{~mm}$; $\mathrm{p}$ $=0.23)$ in the $2.5-\mathrm{U}$ group, and $-15.9 \mathrm{~mm}(95 \% \mathrm{CI}-29.0$ to $-2.7 \mathrm{~mm} ; \mathrm{p}=0.01$ ) in the $5-\mathrm{U}$ group compared with the placebo group (Fig. 4), with significant differences observed for the 1.25-U and 5-U groups. The dose-response improvement in worst leg pain at week 13 was not significant $(\mathrm{p}=0.14)$.

The results for the secondary end-point analyses at week 13 after administration are shown in Table 2. Differences in the SLR test results were significant for the 1.25$\mathrm{U}$ group $(\mathrm{p}=0.005)$ and 5 -U group $(\mathrm{p}=0.02)$ compared with the placebo group. Although the improvements in worst back pain, ODI, and SF-36 were not significant, they were considerably and consistently greater in all 3 condoliase groups compared with the placebo group. Changes in objective assessment data, decrease in disc height, and change in intervertebral disc volume were dose responsive 


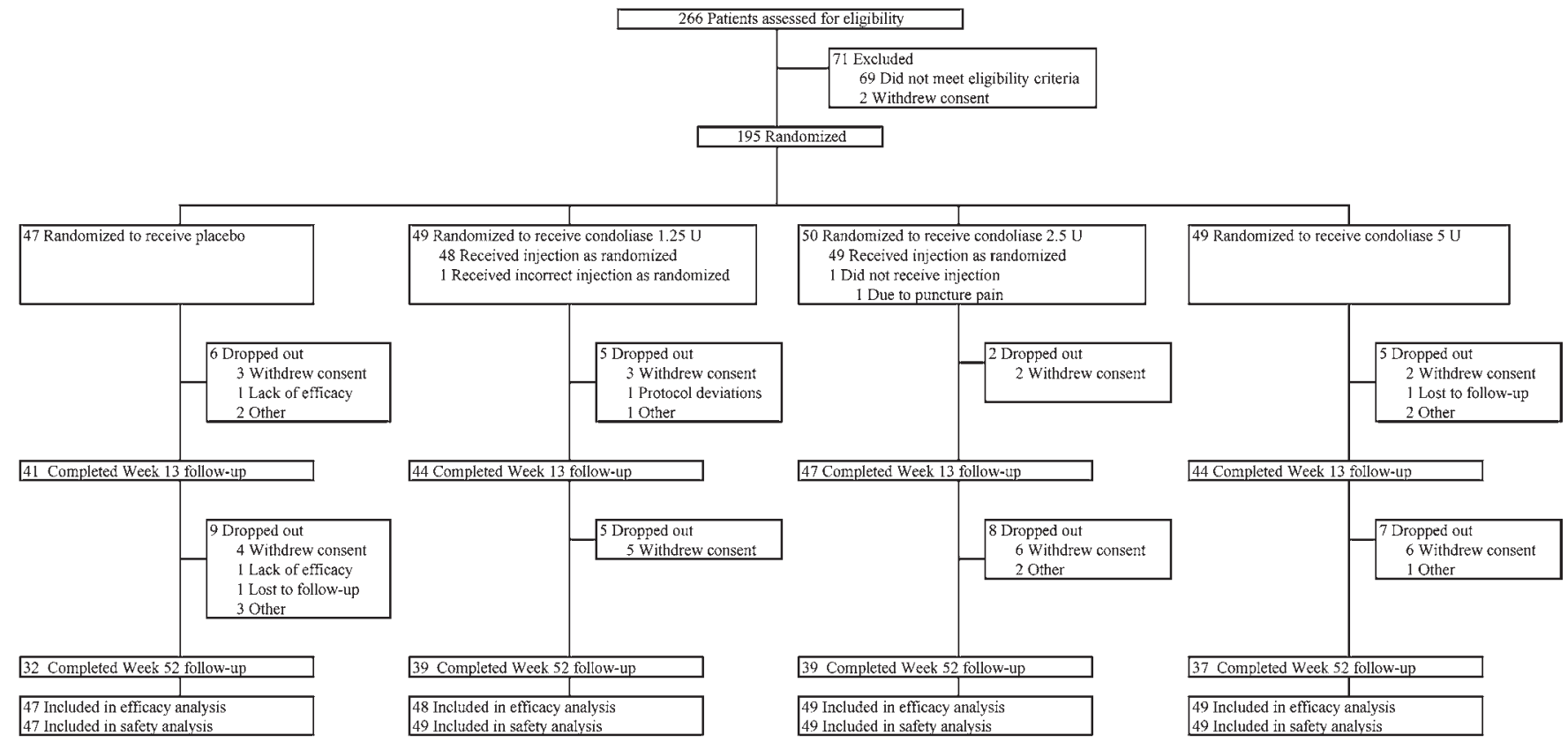

FIG. 2. Flowchart showing patient inclusion.

and significant in all 3 condoliase groups compared with the placebo group ( $p<0.001$ for each). Although no statistically significant difference was noted between treatment groups regarding the change in the volume of the herniated mass, a greater change was observed in the condoliase groups compared with the placebo group.

Negative correlations were observed between the decrease in disc height, the change in intervertebral disc volume, and the $\mathrm{C}_{\max }$ and $\mathrm{AUC}_{\text {last }}$ values for changes in serum keratan sulfate concentrations at week 13. Pearson's correlation coefficients were -0.43 between change in intervertebral disc volume and $\mathrm{C}_{\max }$ and -0.27 between change in intervertebral disc volume and $\mathrm{AUC}_{\text {last }}$. Pearson's correlation coefficients were -0.40 between decrease in disc height and $\mathrm{C}_{\max }$ and -0.32 between decrease in disc height and $\mathrm{AUC}_{\text {last }}$.

The time course for the mean worst leg pain indicated that the decrease in worst leg pain in all 3 condoliase groups began at an early point after administration, with the decreases from week 1 to week 52 being consistently and significantly higher in the $1.25-\mathrm{U}$ and $5-\mathrm{U}$ groups compared with the placebo group. There were no significant differences in the time courses of worst leg pain after administration among the 3 condoliase groups (Fig. 5A). Regarding the other end points, the time courses of the mean worst back pain and percentage change in imaging parameters showed similar trends as the mean worst leg pain, with a tendency for sustained improvement in each of the condoliase groups through week 52 (Fig. 5B and C). Regarding the neurological findings, the percentage of patients who had negative neurological signs also increased over time to $52 \%$ beyond week 13 in each group. The percentages of patients with a negative SLR test finding at week 52 were $81.3 \%$ in the placebo group and $87.2 \%$ to $97.4 \%$ in the condoliase groups.

\section{Safety}

The AEs observed during the study period at week 52 are shown in Table 3. A dose-response relationship was observed in the incidence of adverse drug reactions (ADRs) by treatment group (46.9\% for the $1.25-\mathrm{U}$ group, $44.9 \%$ for the $2.5-\mathrm{U}$ group, and $61.2 \%$ for the $5-\mathrm{U}$ group; $\mathrm{p}<0.001$ ). No patient died or dropped out of the study because of AEs. Five serious AEs occurred in 5 patients (3 patients in the condoliase groups had intervertebral disc protrusion, pneumothorax, and hemorrhoids [ 1 patient each], and 2 patients in the placebo group had convulsion and duodenal ulcer [1 patient each]). All of these serious AEs resolved and were considered to be unrelated to the investigational drug. The intervertebral disc protrusion was a herniation of an intervertebral disc of the lumbar spine (not at the injection site) caused by an external stress (a fall from height at the workplace) 358 days after administration, and resolved 14 days after occurrence after discectomy was performed. Pneumothorax occurred 18 days after administration and was surgically resolved 12 days after occurrence. Hemorrhoids occurred 42 days after administration and resolved 45 days after treatment with hemorrhoidectomy. Severe AEs occurred in 10 patients in the condoliase groups (abnormal hepatic function, intervertebral disc protrusion, lymphadenitis, pneumothorax, hemorrhoids, increase in blood triglyceride level, increase in alanine aminotransferase [ALT] level, and increase in body weight in 1 patient each and decrease in neutrophil count in 2 patients), but all of these resolved or improved. No patient who received condoliase required prolongation of existing hospitalization for treatment of AEs. Intervertebral disc protrusion, pneumothorax, and hemorrhoids were the same events as described above. The investigators considered 2 severe AEs in the 2.5-U group to be related to condoliase (one patient with a decreased neutrophil count and the 
TABLE 1. Demographic and baseline characteristics

\begin{tabular}{|c|c|c|c|c|}
\hline \multirow[b]{2}{*}{ Characteristic } & \multirow[b]{2}{*}{ Placebo } & \multicolumn{3}{|c|}{ Condoliase } \\
\hline & & $1.25 \mathrm{U}$ & $2.5 \mathrm{U}$ & $5 \mathrm{U}$ \\
\hline No. of patients & 47 & 49 & 49 & 49 \\
\hline Age, mean (SD), yrs & $34.0(10.2)$ & $41.9(10.9)$ & $37.9(11.4)$ & $36.2(9.8)$ \\
\hline Female sex, n (\%) & $16(34.0)$ & $11(22.4)$ & $16(32.7)$ & $15(30.6)$ \\
\hline Body mass index, mean (SD), kg/m² & $23.8(2.9)$ & $24.0(3.9)$ & $23.0(3.4)$ & $23.6(3.9)$ \\
\hline Duration of leg pain, median (range), days & $144.0(43-3654)$ & $138.0(49-1218)$ & $147.0(43-1535)$ & $109.0(43-7470)$ \\
\hline \multicolumn{5}{|l|}{ Level of disc herniation, $n(\%)$} \\
\hline L4-5 & $27(57.4)$ & $27(55.1)$ & $23(46.9)$ & $27(55.1)$ \\
\hline L5-S1 & $19(40.4)$ & $22(44.9)$ & $24(49.0)$ & $20(40.8)$ \\
\hline L5-6 & $1(2.1)$ & 0 & $2(4.1)$ & $2(4.1)$ \\
\hline Heavy labor, n (\%) & $25(53.2)$ & $27(55.1)$ & $32(65.3)$ & $37(75.5)$ \\
\hline \multicolumn{5}{|l|}{ Smoking history, $\mathrm{n}(\%)$} \\
\hline Never smoked & $27(57.4)$ & $15(30.6)$ & $19(38.8)$ & $23(46.9)$ \\
\hline Ex-smoker & $3(6.4)$ & $12(24.5)$ & $4(8.2)$ & $7(14.3)$ \\
\hline Current smoker & $17(36.2)$ & $22(44.9)$ & $26(53.1)$ & $19(38.8)$ \\
\hline Worst leg pain, mean (SD), mm & $73.2(12.0)$ & $71.0(14.4)$ & $67.4(12.3)$ & $70.5(12.4)$ \\
\hline Worst back pain, mean (SD), mm & $60.7(26.7)$ & $53.7(27.4)$ & $44.9(27.8)$ & $58.4(23.1)$ \\
\hline ODI score, mean (SD)† & $39.0(14.3)$ & $41.6(15.4)$ & $36.4(13.0)$ & $40.4(16.7)$ \\
\hline \multicolumn{5}{|l|}{ SF-36 score, mean (SD) $\ddagger$} \\
\hline PCS & $24.5(12.3)$ & $18.2(16.3)$ & $22.1(14.1)$ & $21.2(16.9)$ \\
\hline MCS & $44.8(9.8)$ & $46.9(8.7)$ & $47.8(8.5)$ & $48.6(8.3)$ \\
\hline \multicolumn{5}{|l|}{ Positive neurological signs, n (\%) } \\
\hline SLR test§ & $47(100.0)$ & $49(100.0)$ & $49(100.0)$ & $49(100.0)$ \\
\hline Hypesthesia & $28(59.6)$ & $31(63.3)$ & $27(55.1)$ & $31(63.3)$ \\
\hline Muscle weakness & $12(25.5)$ & $12(24.5)$ & $12(24.5)$ & $13(26.5)$ \\
\hline Diminished deep tendon reflex & $7(14.9)$ & $12(24.5)$ & $9(18.4)$ & $16(32.7)$ \\
\hline Hernia vol, mean (SD), $\mathrm{cm}^{3}$ & $1.39(0.51)$ & $1.49(0.52)$ & $1.22(0.42)$ & $1.44(0.52)$ \\
\hline Intervertebral disc vol, mean (SD), $\mathrm{cm}^{3}$ & $13.30(3.70)$ & $14.66(3.70)$ & $12.87(4.03)$ & $14.52(4.02)$ \\
\hline Disc height, mean (SD)ף & $0.259(0.042)$ & $0.259(0.060)$ & $0.262(0.050)$ & $0.260(0.056)$ \\
\hline Posterior intervertebral angle $\left(^{\circ}\right)$, mean (SD) & $3.252(5.354)$ & $4.122(5.693)$ & $4.010(4.955)$ & $1.913(6.011)$ \\
\hline Vertebral translation, mean (SD), mm & $0.743(0.644)$ & $0.858(0.670)$ & $0.863(0.677)$ & $1.082(0.849)$ \\
\hline \multicolumn{5}{|l|}{ Modic type, n (\%) } \\
\hline 0 & $39(83.0)$ & $38(77.6)$ & $41(83.7)$ & $39(79.6)$ \\
\hline 1 & $5(10.6)$ & $9(18.4)$ & $7(14.3)$ & $8(16.3)$ \\
\hline 2 & $3(6.4)$ & $2(4.1)$ & $1(2.0)$ & $2(4.1)$ \\
\hline 3 & 0 & 0 & 0 & 0 \\
\hline \multicolumn{5}{|l|}{ Pfirrmann grade, $\mathrm{n}(\%)$} \\
\hline 0 & 0 & 0 & 0 & $3(6.1)$ \\
\hline 1 & $4(8.5)$ & $3(6.1)$ & $4(8.2)$ & 7 (14.3) \\
\hline 2 & 34 (72.3) & 38 (77.6) & $34(69.4)$ & $30(61.2)$ \\
\hline 3 & 9 (19.1) & 8 (16.3) & $11(22.4)$ & $9(18.4)$ \\
\hline
\end{tabular}

MCS = mental component summary; PCS = physical component summary.

* Patients assessed their own pain levels before going to bed. The intensity of pain was measured on a horizontal 100-mm VAS, with 0 mm representing "no pain" and

$100 \mathrm{~mm}$ representing "worst pain ever experienced." VAS at baseline was measured on the last 7 consecutive days before patient enrollment.

$\dagger$ The scale ranged from 0 to 100, with a higher score indicating more severe symptoms.

$\ddagger$ PCS and MCS were scored as having a mean (SD) of $50(10)$ in the general Japanese population. ${ }^{8} \mathrm{~A}$ higher score indicates less severe symptoms.

$\S$ The SLR test was defined as positive for values $\leq 70^{\circ}$.

II Disc height $=$ (anterior disc height + posterior disc height $) /(2 \times$ upper vertebral body height). 


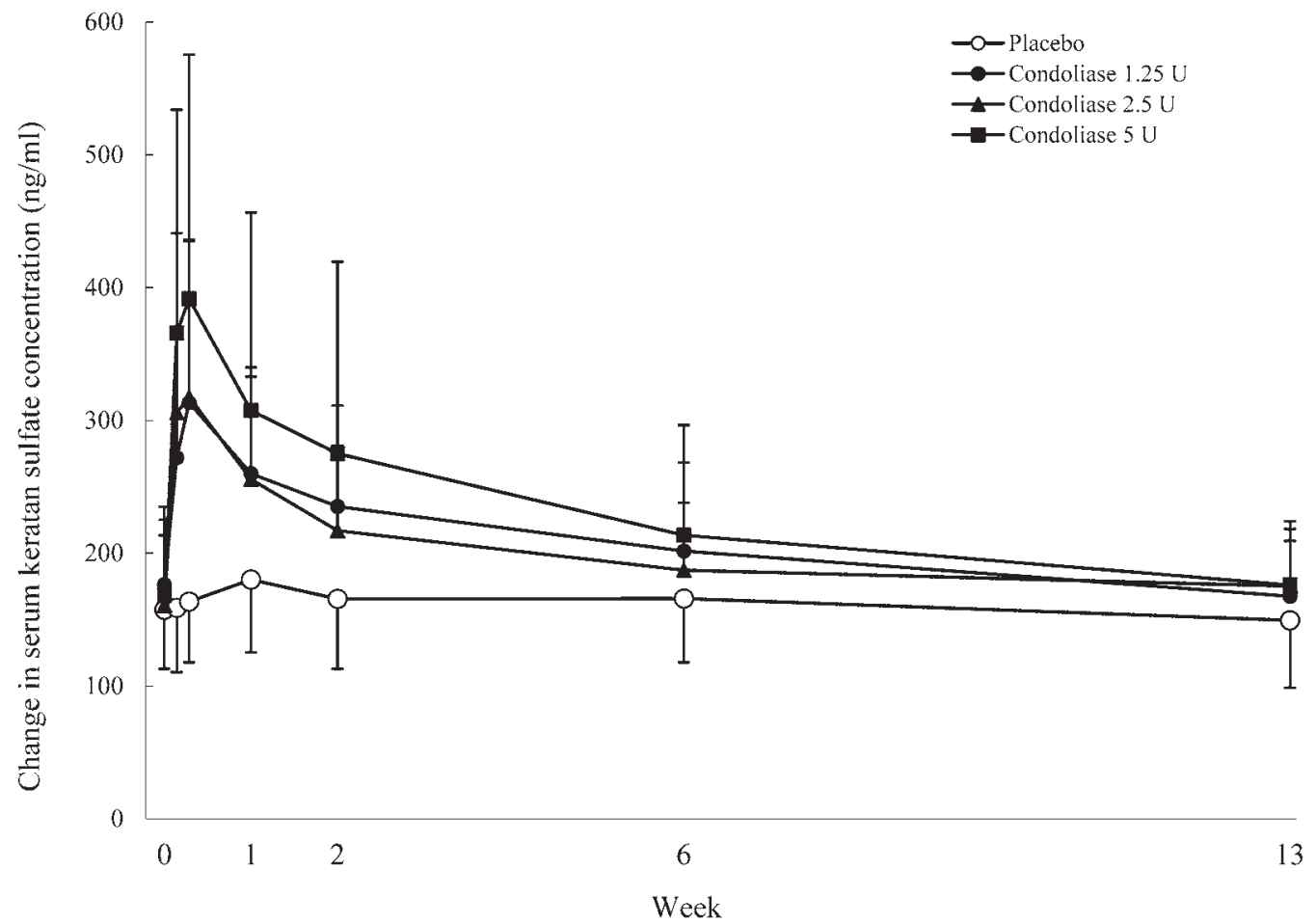

FIG. 3. Effects of condoliase treatment on serum keratan sulfate concentration. The data represent mean and SD (whiskers) values.

other with lymphadenitis). The decrease in the neutrophil count occurred 2 days after administration and resolved 167 days after occurrence without special treatment. The neutrophil count was $2.70 \times 10^{3} / \mu \mathrm{l}$ before administration and decreased to $0.98 \times 10^{3} / \mu 1$ at 7 days after administration. Lymphadenitis occurred 40 days after administration and resolved 59 days after occurrence following medical treatment. Accompanying this event, ALT increased from

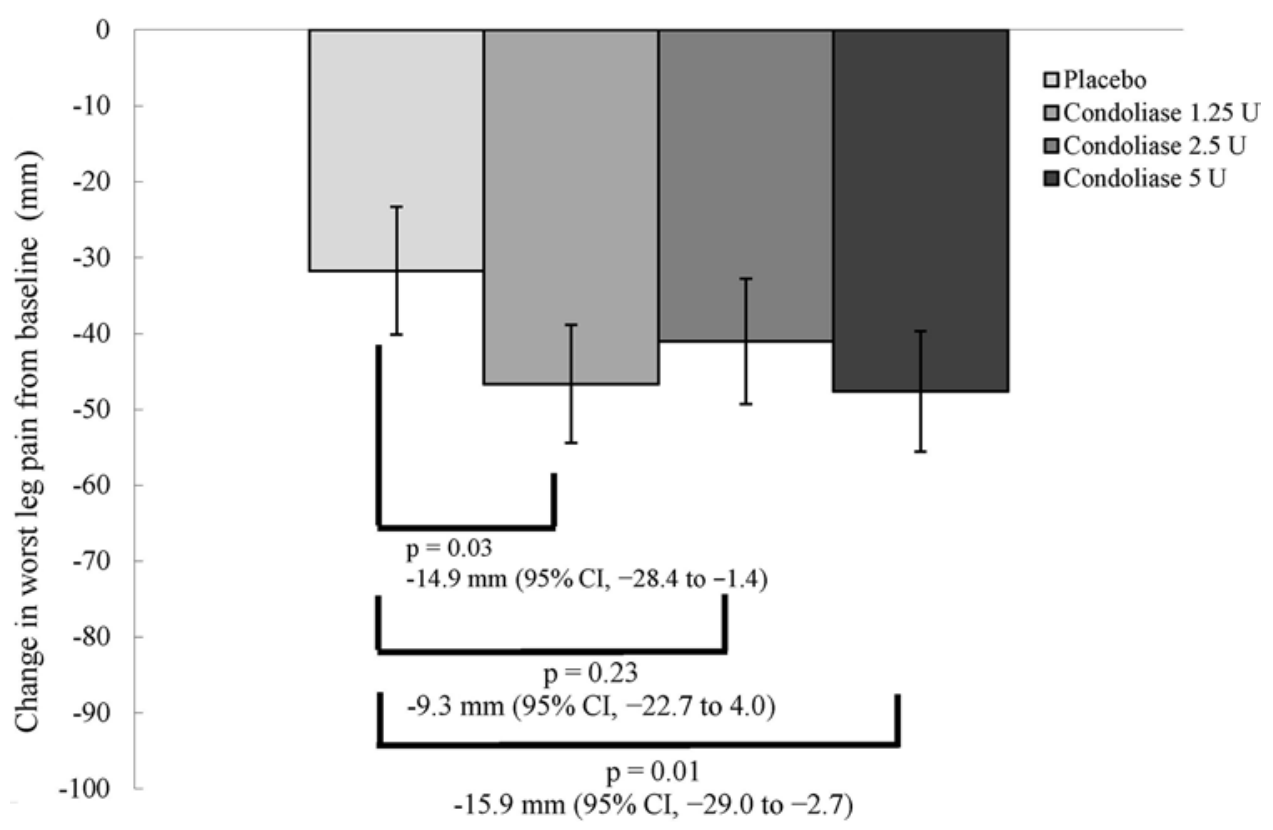

FIG. 4. Effects of condoliase on the worst leg pain. Patients assessed their own pain levels before going to bed. The intensity of pain was measured on a horizontal $100-\mathrm{mm}$ VAS, with $0 \mathrm{~mm}$ representing "no pain" and $100 \mathrm{~mm}$ representing "worst pain ever experienced." Changes in the worst leg pain from preadministration to week 13 are shown. Data represent least-squares means and $95 \%$ confidence intervals (whiskers). VAS at preadministration was measured on the last 7 consecutive days before patient enrollment, and VAS at week 13 was measured on the last 7 consecutive days before observation. VAS values were analyzed by using ANCOVA, and missing values were imputed using the last observation carried forward method. 


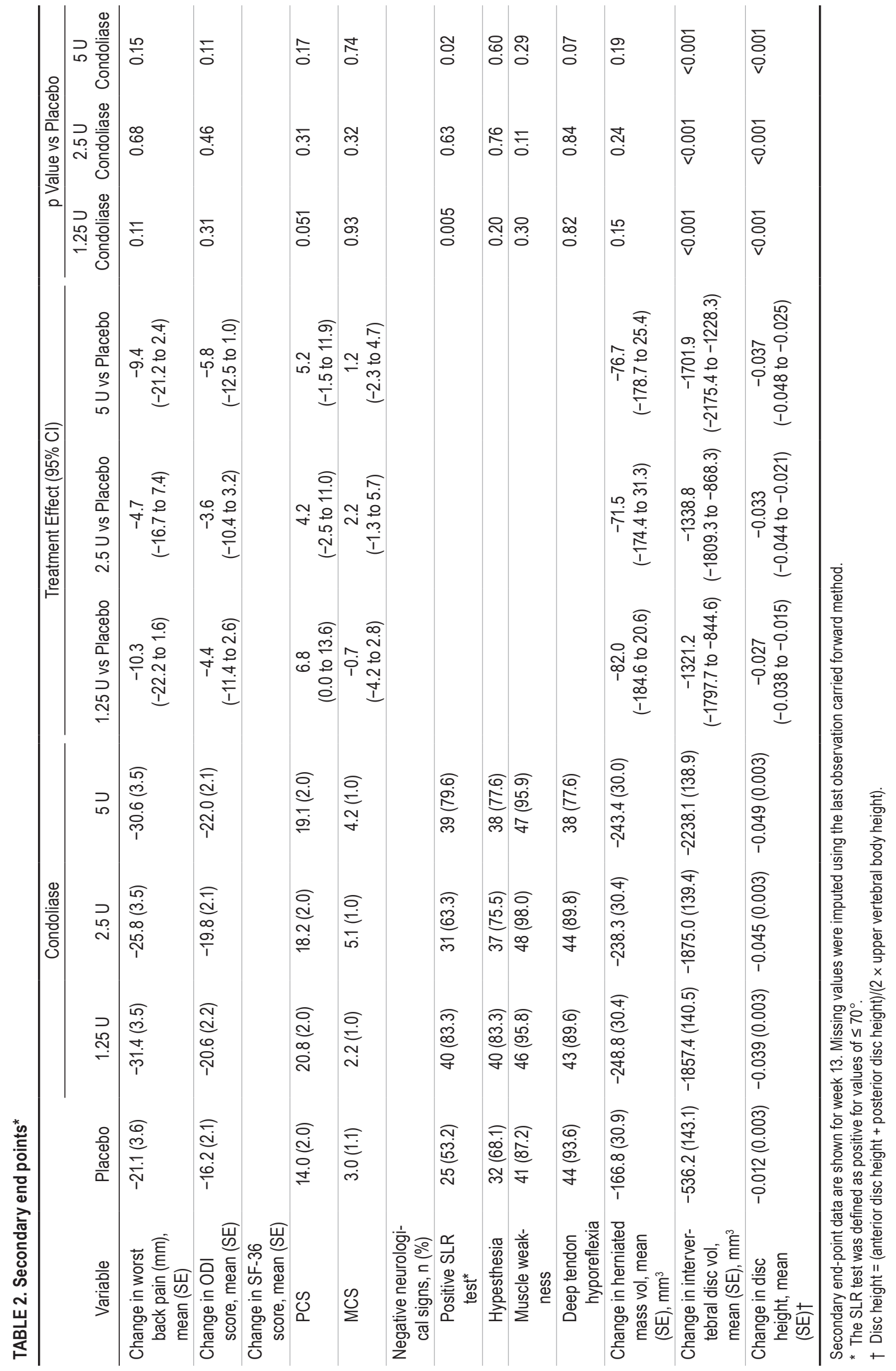



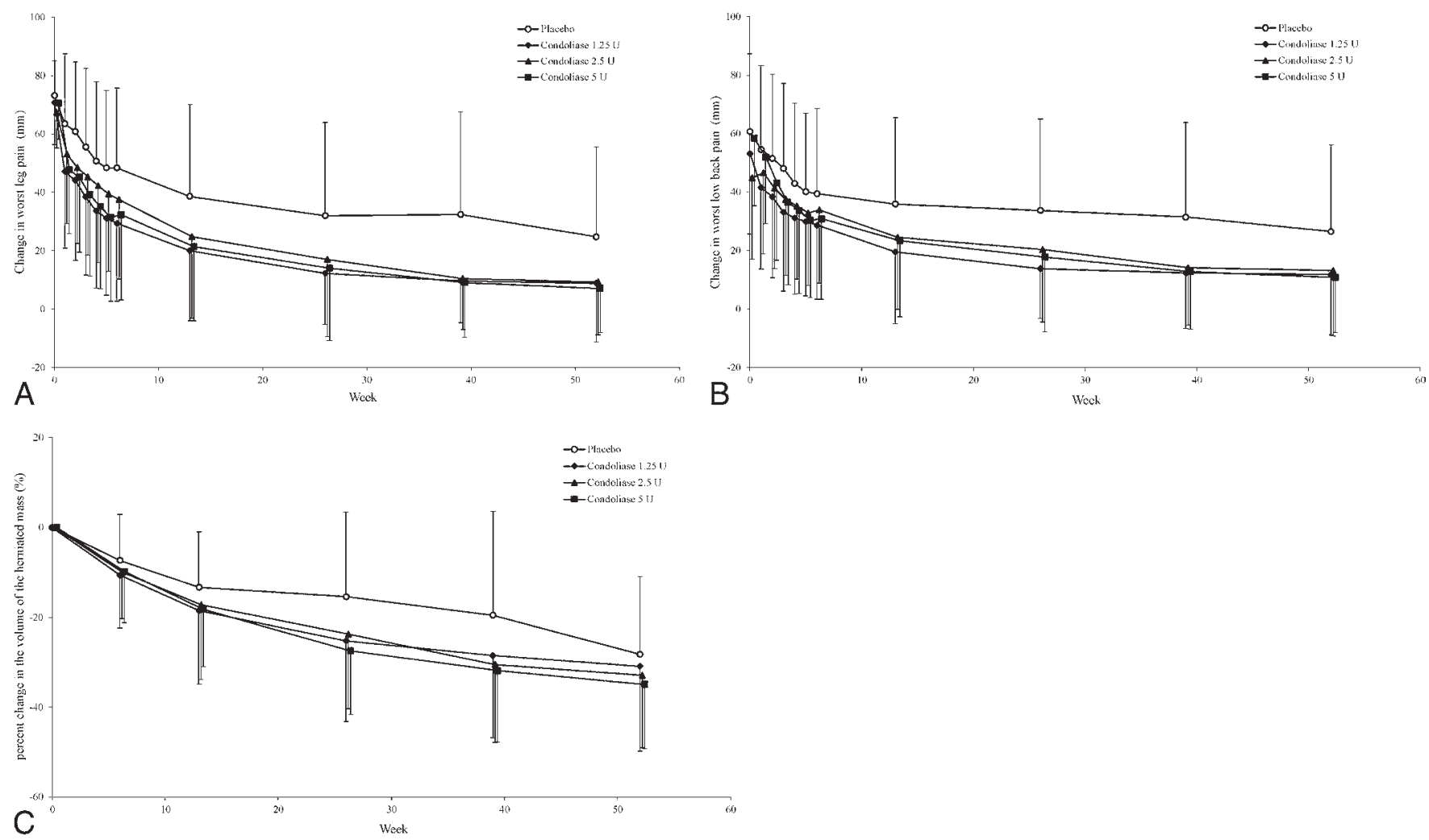

FIG. 5. Time courses from preadministration to week 52. A: Mean worst leg pain. B: Mean worst back pain. C: Percentage change in the volume of the herniated mass. Data represent the mean and SD (whiskers). VAS at preadministration was measured on the last 7 consecutive days before patient enrollment, VAS from the day of administration to week 6 was consecutively measured, VAS at week 13 was measured on the last 7 consecutive days before observation, and VAS at weeks 26, 39, and 52 was measured on the day before observation.

$79 \mathrm{U} / \mathrm{L}$ before administration to $239 \mathrm{U} / \mathrm{L}$ at 63 days after administration. Other severe AEs were considered by the investigator to be unrelated to the investigational drug. The details of the other events are as follows: For abnormal hepatic function, ALT, aspartate aminotransferase, and lactate dehydrogenase gradually increased 7 days after administration and recovered to normal values after discontinuation of concomitant drugs. For the decrease in neutrophil count, the count decreased to $0.99 \times 10^{3} / u 17$ days after administration and recovered 36 days after occurrence. For the increase in blood triglyceride level, the level increased to $1363 \mathrm{mg} / \mathrm{dl} 43$ days after administration and recovered 22 days after occurrence without special treatment. For the increase in the ALT level, the level increased to 137 U/L 38 days after administration and recovered about 300 days after occurrence. For the increase in body weight, it increased by $20 \%$ or more at 97 days after administration compared with that measured before administration.

Back pain was the most common $\mathrm{AE}$ in the condoliase groups, with an incidence of $26.5 \%$ to $36.7 \%$, and occurred within 1 week of administration in most cases and resolved within 1 month. Severity was mild to moderate in all patients. Allergy-like symptoms were observed in 4 patients in the condoliase groups. All 4 AEs were moderate, occurred within 2 days of administration, and resolved after drug treatment.

No patient exhibited elevated serum anticondoliase im- munoglobulin E ( $\operatorname{IgE}$ ) antibody titers. Two patients in the 2.5-U and 5-U groups exhibited elevated serum anticondoliase IgG antibody titers.

Imaging findings observed during the study period at week 52 are shown in Table 4. Modic type 1 change, decrease of $\geq 30 \%$ in disc height, change in Pfirrmann classification grade, and posterior intervertebral angle of $\geq 5^{\circ}$ were frequently observed in the condoliase groups. The proportions of patients with a decrease of $\geq 30 \%$ in disc height $(15.4 \%$ in the $1.25-\mathrm{U}$ group, $12.8 \%$ in the $2.5-\mathrm{U}$ group, and $24.3 \%$ in the 5-U group) and a change in disc height $(-16.4 \%$ in the $1.25-\mathrm{U}$ group, $-17.2 \%$ in the $2.5-\mathrm{U}$ group, and $-20.4 \%$ in the 5 -U group) were dose responsive $(p<0.001$ for each). There was no increase in the incidence of leg pain or back pain that accompanied these imaging findings.

\section{Illustrative Case}

We present a typical case of Modic type 1 change and decrease in disc height as follows. A 29-year-old man with L5-6 disc herniation presented with right-leg pain consistent with the distribution of compressed nerve roots (Fig. 6 upper). After he received an intradiscal injection of 2.5 $\mathrm{U}$ of condoliase, Modic type 1 change occurred and lasted from week 6 to week 52 (Fig. 6 lower). The change in disc height from baseline was $-32.0 \%$ at week 52 , and hernia- 
TABLE 3. Adverse events

\begin{tabular}{|c|c|c|c|c|}
\hline \multirow[b]{2}{*}{ Variable } & \multirow[b]{2}{*}{ Placebo } & \multicolumn{3}{|c|}{ Condoliase } \\
\hline & & $1.25 \mathrm{U}$ & $2.5 \mathrm{U}$ & $5 U$ \\
\hline No. of patients & 47 & 49 & 49 & 49 \\
\hline Adverse events & $35(74.5)$ & $38(77.6)$ & $41(83.7)$ & $42(85.7)$ \\
\hline ADR & $7(14.9)$ & $23(46.9)$ & $22(44.9)$ & $30(61.2)$ \\
\hline AE leading to dropout & 0 & 0 & 0 & 0 \\
\hline Serious $\mathrm{AE}^{*}$ & $2(4.3)$ & $1(2.0)$ & $2(4.1)$ & 0 \\
\hline Severe AE† & 0 & $3(6.1)$ & $5(10.2)$ & $2(4.1)$ \\
\hline \multicolumn{5}{|l|}{ Common AE $\neq$} \\
\hline Back pain & $18(38.3)$ & $18(36.7)$ & $13(26.5)$ & $14(28.6)$ \\
\hline Leg pain & $12(25.5)$ & $8(16.3)$ & $6(12.2)$ & $9(18.4)$ \\
\hline Nasopharyngitis & $4(8.5)$ & $8(16.3)$ & $4(8.2)$ & $4(8.2)$ \\
\hline Injection site pain & 0 & $4(8.2)$ & $4(8.2)$ & $1(2.0)$ \\
\hline Increase in ALT level & 0 & $1(2.0)$ & $2(4.1)$ & $4(8.2)$ \\
\hline $\begin{array}{l}\text { Decrease in neutrophil } \\
\text { count }\end{array}$ & $2(4.3)$ & $2(4.1)$ & $2(4.1)$ & $3(6.1)$ \\
\hline $\begin{array}{l}\text { Increase in } \\
\gamma \text {-glutamyltransferase } \\
\text { level }\end{array}$ & 0 & 0 & $3(6.1)$ & $2(4.1)$ \\
\hline $\begin{array}{l}\text { Increase in aspartate } \\
\text { aminotransferase } \\
\text { level }\end{array}$ & 0 & 0 & $1(2.0)$ & $3(6.1)$ \\
\hline Allergy-like symptoms§ & $1(2.1)$ & $2(4.1)$ & $1(2.0)$ & $1(2.0)$ \\
\hline
\end{tabular}

Values are presented as number (\%)

* A serious AE was any event that occurred during the study period, whether or not it was related to the investigational drug, that resulted in death, was considered life-threatening, required inpatient hospitalization or prolongation of existing hospitalization for treatment, resulted in persistent or significant disability or incapacity, resulted in a congenital anomaly or birth defect, or caused other events or reactions that were considered medically significant. In the condoliase groups, intervertebral disc protrusion occurred in 1 patient (1.25-U condoliase group) and pneumothorax and hemorrhoids occurred in 1 patient each (2.5-U condoliase group). In the placebo group, convulsion and duodenal ulcer occurred in 1 patient each.

† A severe AE was defined as any event that was disabling or required systemic treatment (Common Terminology Criteria for Adverse Events grade 3 or 4). In the condoliase groups, abnormal hepatic function, intervertebral disc protrusion, and decrease in neutrophil count occurred in 1 patient each (1.25-U condoliase group); lymphadenitis, pneumothorax, hemorrhoids, decrease in neutrophil count, and increase in blood triglyceride level occurred in 1 patient each (2.5-U condoliase group); and increase in ALT level and increase in body weight occurred in 1 patient each ( $5-U$ condoliase group).

$\ddagger$ Common AEs occurred in $\geq 5 \%$ of patients in the condoliase groups. $\S$ In the condoliase groups, urticaria and toxic skin eruption occurred in 1 patient each (1.25-U condoliase group); drug eruption occurred in 1 patient (2.5-U condoliase group); and rash occurred in 1 patient (5-U condoliase group). In the placebo group, rash occurred in 1 patient.

tion was reduced after injection. His leg pain and back pain almost vanished the day after injection. The patient completed the study without any clinically important AEs.

\section{Discussion}

The present study was conducted to determine the most suitable therapeutic dose for condoliase injection into the nucleus pulposus of the intervertebral disc by evaluating its pharmacokinetics, efficacy, and safety compared with placebo injection.

The change in the serum concentration of keratan sul- fate, a component of the nucleus pulposus, showed negative correlations with intervertebral disc volume and disc height. These findings suggest that the serum keratan sulfate concentration is a parameter associated with the dissolution of the nucleus pulposus. A significant increase in the serum keratan sulfate concentration was observed up to week 6 after administration. Meanwhile, improvement in worst leg pain lasted for at least 1 year after administration. Therefore, improvement in LDH symptoms by condoliase treatment was considered to last beyond the disappearance of the nucleus pulposus-dissolving effect.

The difference in the change in the VAS score for leg pain, from screening to week 13 , between the $1.25-\mathrm{U}$ and 5 -U condoliase groups and the placebo group was about $15 \mathrm{~mm}$. In a randomized clinical trial that compared outcomes after herniation surgery versus conservative treatment in LDH patients, the difference between groups at 4-8 weeks after treatment was a maximum of $20 \mathrm{~mm} .^{20}$ Although no direct comparison with herniation surgery was performed, the $15-\mathrm{mm}$ difference from the placebo group observed at week 13 in this study, which is the primary end point, is considered significantly meaningful because no large difference was noted compared with the value for herniation surgery. In addition, with regard to the secondary end point, although no statistically significant difference with the placebo group was noted, the VAS scores for leg pain and back pain in both condoliase groups decreased to $30 \mathrm{~mm}$ or lower at week 13, thus indicating that condoliase improved pain to levels that were clinically insignificant. ${ }^{4}$ In addition, the ODI in each condoliase group improved to a level close to that considered to represent minimal disability. ${ }^{7}$ Based on these results, it was concluded that the effect of condoliase is clinically meaningful. The long-term efficacy of condoliase must be determined in the future by evaluating the persistence of improvement in leg pain and quality of life over 1 year after administration and the herniation recurrence rate.

Regarding safety, no deaths, clinically important AEs, or AEs requiring prolongation of the existing 2-day hospitalization to ensure patient safety were seen. No elevations in serum anticondoliase $\mathrm{IgE}$ antibody titers were observed, and anaphylaxis did not occur in the present study. In a study on chemonucleolysis with chymopapain, a proteolytic enzyme, anaphylaxis occurred in $0.5 \%$ of patients after administration. ${ }^{25}$ Because condoliase is also a foreign protein, ${ }^{29}$ the risk of anaphylaxis cannot be excluded. Because chymopapain is derived from papain, which is widely used as a meat tenderizer, ${ }^{16,24}$ sensitization may be more common for chymopapain, while the possibility of similar sensitization to condoliase may be low. However, further information needs to be collected from more patients to fully evaluate its safety.

Regarding the changes in the vertebral body and its surrounding tissues, Modic type 1 change and progression of intervertebral disc degeneration occurred at a high frequency in the condoliase groups, and the number of patients with a decrease of $\geq 30 \%$ in disc height increased in a dose-dependent manner. While some previous studies found that these imaging findings were associated with back pain, ${ }^{1,14,18,31}$ no clear relationships between imaging findings and the occurrence of clinical symptoms were 
TABLE 4. Imaging findings

\begin{tabular}{|c|c|c|c|c|}
\hline \multirow[b]{2}{*}{ Variable } & \multirow[b]{2}{*}{ Placebo } & \multicolumn{3}{|c|}{ Condoliase } \\
\hline & & $1.25 \mathrm{U}$ & $2.5 \mathrm{U}$ & $5 \mathrm{U}$ \\
\hline No. of patients & 32 & 39 & 39 & 37 \\
\hline \multicolumn{5}{|l|}{ Modic type, $\mathrm{n}(\%)$} \\
\hline 1 & $2(6.3)$ & $14(35.9)$ & $17(43.6)$ & $14(37.8)$ \\
\hline 2 & 0 & 0 & 0 & 0 \\
\hline 3 & 0 & 0 & 0 & 0 \\
\hline \multicolumn{5}{|l|}{ Disc height } \\
\hline Decrease in disc height $\geq 30 \%, n(\%)$ & 0 & $6(15.4)$ & $5(12.8)$ & $9(24.3)$ \\
\hline Change in disc height, mean (SD) & $-8.4(5.5)$ & $-16.4(10.2)$ & $-17.2(9.3)$ & $-20.4(10.7)$ \\
\hline \multicolumn{5}{|l|}{ Posterior intervertebral angle } \\
\hline Posterior intervertebral angle $\geq 5^{\circ}, \mathrm{n}(\%)$ & $3(9.4)$ & $3(7.7)$ & $1(2.6)$ & $4(10.8)$ \\
\hline Posterior intervertebral angle $\left({ }^{\circ}\right)$, mean (SD) & $3.0(4.9)$ & $3.8(5.6)$ & $2.8(4.4)$ & $2.1(4.7)$ \\
\hline \multicolumn{5}{|l|}{ Vertebral translation } \\
\hline Vertebral translation $\geq 3$ mm, n (\%) & 0 & 0 & 0 & 0 \\
\hline Vertebral translation, mean (SD), mm & $0.9(0.76)$ & $0.6(0.55)$ & $0.8(0.70)$ & $0.7(0.64)$ \\
\hline Pfirrmann grade change, $\mathrm{n}(\%)$ & $4(12.5)$ & $18(46.2)$ & $13(33.3)$ & $17(45.9)$ \\
\hline
\end{tabular}

observed in the present study. However, because these imaging findings were considered condoliase related, the long-term effects of condoliase on the vertebral body and its surrounding tissues should be further examined.

In our previous study, ${ }^{17}$ improvements in worst leg pain and neurological symptoms were not clinically sufficient at $0.5-\mathrm{U}$ condoliase doses. In the present dose-finding study, the efficacies of the 3 doses of condoliase $(1.25,2.5$, and
$5 \mathrm{U})$ were equivalent and clinically meaningful. However, dose-response relationships were observed for the incidence of ADRs and changes in imaging parameters, such as decrease in disc height. Therefore, we consider $1.25 \mathrm{U}$ to be a suitable therapeutic dose of condoliase.

Condoliase administration involves the same technique as discography, but it is less invasive and no clinically important AEs occurred during the present study.

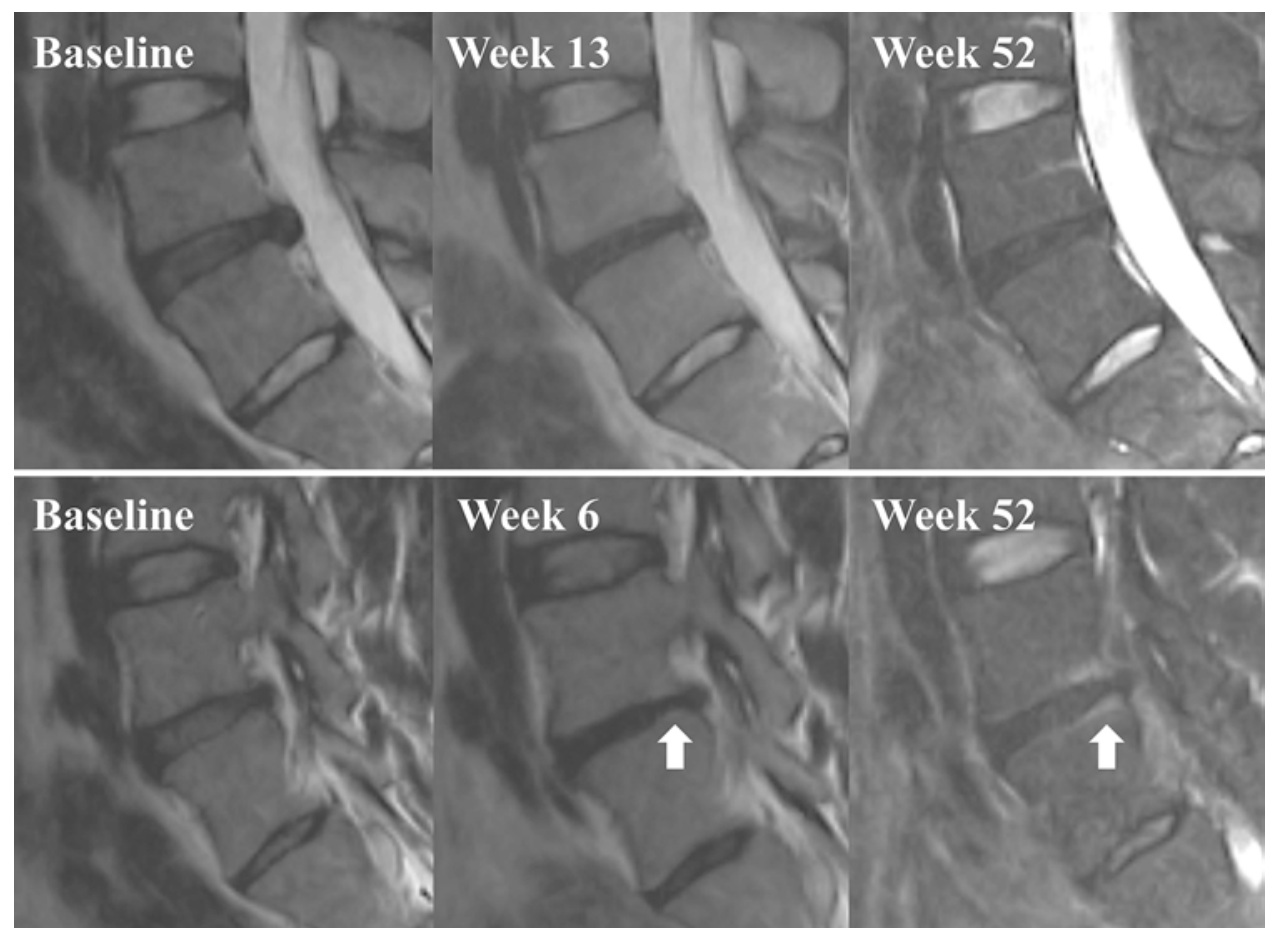

FIG. 6. Changes in T2-weighted sagittal images after condoliase treatment. Upper: L5-6 disc herniation. Herniation was greatly reduced after condoliase injection. Lower: Modic type 1 change (arrow) was observed in the superior and inferior vertebral body of the injected intervertebral disc at week 6 . 
We believe that condoliase will contribute to patients with $\mathrm{LDH}$ achieving an early return to work, given that LDH frequently occurs in working adults.

\section{Conclusions}

The present study demonstrates that condoliase was superior to placebo and significantly improved leg pain. Regarding safety, condoliase was well tolerated and did not cause any serious ADRs. While the 1.25-, 2.5-, and 5-U groups showed similar efficacies, the incidence of ADRs and decrease in disc height were dose dependent. Therefore, we concluded that $1.25 \mathrm{U}$ would be the most suitable therapeutic dose of condoliase for patients with LDH.

\section{Acknowledgments}

We thank the following participating investigators for their contributions to data acquisition: N. Kawakami, K. Shigenobu, S. Ito, F. Kato, T. Tokioka, M. Deguchi, M. Shioda, K. Sato, S. Satoh, H. Hyodo, M. Kayaoka, E. Okada, K. Shirasawa, M. Kamata, K. Ninomiya, T. Teruya, K. Okuyama, Y. Ito, M. Takahashi, H. Okai, T. Yoshimura, M. Yamagata, A. Harada, M. Hoshino, M. Sasaki, T. Urasaki, I. Sato, H. Kano, M. Yanase, M. Shimode, T. Uchida, H. Machida, Y. Koizumi, T. Kodama, K. Suzuki, K. Yamamoto, T. Kataoka, E. Yorimitsu, T. Ueda, Y. Kaneko, N. Takada, N. Sha, and $\mathrm{H}$. Yoshida. In addition, we thank M. Yamagata, S. Asano, K. Hasegawa, and T. Toyone for their contributions to additional imaging assessments, and the clinical staff members at all participating hospitals for their support and contributions to the study.

\section{References}

1. Albert HB, Manniche C: Modic changes following lumbar disc herniation. Eur Spine J 16:977-982, 2007

2. Arts MP, Peul WC, Koes BW, Thomeer RT: Management of sciatica due to lumbar disc herniation in the Netherlands: a survey among spine surgeons. J Neurosurg Spine 9:32-39, 2008

3. Caspar W: A new surgical procedure for lumbar disk herniation causing less tissue damage through a microsurgical approach. Adv Neurosurg 4:74-80, 1977

4. Collins SL, Moore RA, McQuay HJ: The visual analogue pain intensity scale: what is moderate pain in millimetres? Pain 72:95-97, 1997

5. Dora C, Schmid MR, Elfering A, Zanetti M, Hodler J, Boos $\mathrm{N}$ : Lumbar disk herniation: do MR imaging findings predict recurrence after surgical diskectomy? Radiology 235:562567,2005

6. Fairbank JC, Couper J, Davies JB, O'Brien JP: The Oswestry low back pain disability questionnaire. Physiotherapy 66:271-273, 1980

7. Fairbank JC, Pynsent PB: The Oswestry Disability Index. Spine (Phila Pa 1976) 25:2940-2952, 2000

8. Fukuhara S, Suzukamo Y: Manual of SF-36v2 Japanese Version. Kyoto: Institute for Health Outcomes \& Process Evaluation Research, 2004

9. Gibson JN, Grant IC, Waddell G: The Cochrane review of surgery for lumbar disc prolapse and degenerative lumbar spondylosis. Spine (Phila Pa 1976) 24:1820-1832, 1999

10. Hamai A, Hashimoto N, Mochizuki H, Kato F, Makiguchi Y, Horie K, et al: Two distinct chondroitin sulfate ABC lyases. An endoeliminase yielding tetrasaccharides and an exoeliminase preferentially acting on oligosaccharides. J Biol Chem 272:9123-9130, 1997

11. Ito T, Takano Y, Yuasa N: [Reduction of the number of herniotomies by conservative treatments.] Rinsyo Seikeigeka 36:487-490, 2001 (Jpn)
12. Japan Spine Research Society (ed): [Dictionary of Spinal Disorders.] Tokyo: Nankodo, 1995 (Jpn)

13. Kawabata M: [Lumbar disc herniation.] Rinsyo Seikeigeka 24:825-831, 1989 (Jpn)

14. Kjaer P, Korsholm L, Bendix T, Sorensen JS, Leboeuf-Yde C: Modic changes and their associations with clinical findings. Eur Spine J 15:1312-1319, 2006

15. Litcher-Kelly L, Martino SA, Broderick JE, Stone AA: A systematic review of measures used to assess chronic musculoskeletal pain in clinical and randomized controlled clinical trials. J Pain 8:906-913, 2007

16. Mansfield LE, Bowers CH: Systemic reaction to papain in a nonoccupational setting. J Allergy Clin Immunol 71:371374, 1983

17. Matsuyama Y: [Intradiscal therapy for low back pain.] Rinsyo Seikeigeka 42:223-228, 2007 (Jpn)

18. Mochida J, Nishimura K, Nomura T, Toh E, Chiba M: The importance of preserving disc structure in surgical approaches to lumbar disc herniation. Spine (Phila Pa 1976) 21:1556-1564, 1996

19. Modic MT, Steinberg PM, Ross JS, Masaryk TJ, Carter JR: Degenerative disk disease: assessment of changes in vertebral body marrow with MR imaging. Radiology 166:193-199, 1988

20. Peul WC, van Houwelingen HC, van den Hout WB, Brand R, Eekhof JA, Tans JT, et al: Surgery versus prolonged conservative treatment for sciatica. N Engl J Med 356:2245-2256, 2007

21. Pfirrmann CW, Metzdorf A, Elfering A, Hodler J, Boos N: Effect of aging and degeneration on disc volume and shape: A quantitative study in asymptomatic volunteers. J Orthop Res 24:1086-1094, 2006

22. Pfirrmann CW, Metzdorf A, Zanetti M, Hodler J, Boos N: Magnetic resonance classification of lumbar intervertebral disc degeneration. Spine (Phila Pa 1976) 26:1873-1878, 2001

23. Pocock SJ, Simon R: Sequential treatment assignment with balancing for prognostic factors in the controlled clinical trial. Biometrics 31:103-115, 1975

24. Sagona MA, Bruszer GV, Nelson JC, Mascoli C, Serkes K: Reactivity of IgE and IgG serum levels to chymopapain after chemonucleolysis. J Allergy Clin Immunol 75:659-662, 1985

25. Simmons JW, Nordby EJ, Hadjipavlou AG: Chemonucleolysis: the state of the art. Eur Spine J 10:192-202, 2001

26. Spangfort EV: The lumbar disc herniation. A computer-aided analysis of 2,504 operations. Acta Orthop Scand Suppl 142:1-95, 1972

27. Wang H, Huang B, Li C, Zhang Z, Wang J, Zheng W, et al: Learning curve for percutaneous endoscopic lumbar discectomy depending on the surgeon's training level of minimally invasive spine surgery. Clin Neurol Neurosurg 115:19871991, 2013

28. Wong DA, Transfeldt E: Macnab's Backache, ed 4. Philadelphia: Lippincott Williams and Wilkins, 2007, pp 77-83

29. Yamagata T, Saito H, Habuchi O, Suzuki S: Purification and properties of bacterial chondroitinases and chondrosulfatases. J Biol Chem 243:1523-1535, 1968

30. Yasargil MG: Microsurgical operation of herniated lumbar disc. Adv Neurosurg 4:81, 1977

31. Yorimitsu E, Chiba K, Toyama Y, Hirabayashi K: Long-term outcomes of standard discectomy for lumbar disc herniation: a follow-up study of more than 10 years. Spine (Phila Pa 1976) 26:652-657, 2001

\section{Disclosures}

This study was funded by the Seikagaku Corp. The investiga- 
tional drugs (condoliase and placebo) were produced by the Seikagaku Corp. The 21- to 23-gauge puncture needles used for injection were provided by the Seikagaku Corp.

Dr. Chiba: clinical or research support, consulting fees, and travel expenses from Seikagaku Corp. Dr. Iwata: research funds and travel expenses from Seikagaku Corp. Dr. Matsuyama: clinical or research support, consulting fees, and travel expenses from Seikagaku Corp. Dr. Seo: employee of and research funds and travel expenses from Seikagaku Corp. Dr. Toyama: consultant for and research funds and travel expenses from Seikagaku Corp.

Drs. Yamagata, Asano, Hasegawa, and Toyone (participating investigators): consulting fees from Seikagaku Corp. All participating investigators have received research funds and travel expenses to participate in investigational meetings from Seikagaku Corp.

\section{Author Contributions}

Conception and design: Matsuyama, Chiba, Iwata, Toyama.
Analysis and interpretation of data: Matsuyama, Chiba. Drafting the article: Matsuyama. Critically revising the article: Matsuyama, Chiba. Reviewed submitted version of manuscript: Matsuyama, Chiba. Approved the final version of the manuscript on behalf of all authors: Matsuyama. Statistical analysis: Seo. Administrative/ technical/material support: Matsuyama, Chiba. Study supervision: Matsuyama, Chiba.

\section{Supplemental Information \\ Previous Presentations}

This study was presented, in part, at the 44th Annual Meeting of the Japanese Society for Spine Surgery and Related Research on April 16-18, 2015, in Fukuoka, Japan.

\section{Correspondence}

Yukihiro Matsuyama: Hamamatsu University School of Medicine, Shizuoka, Japan. spine-yu@hama-med.ac.jp. 